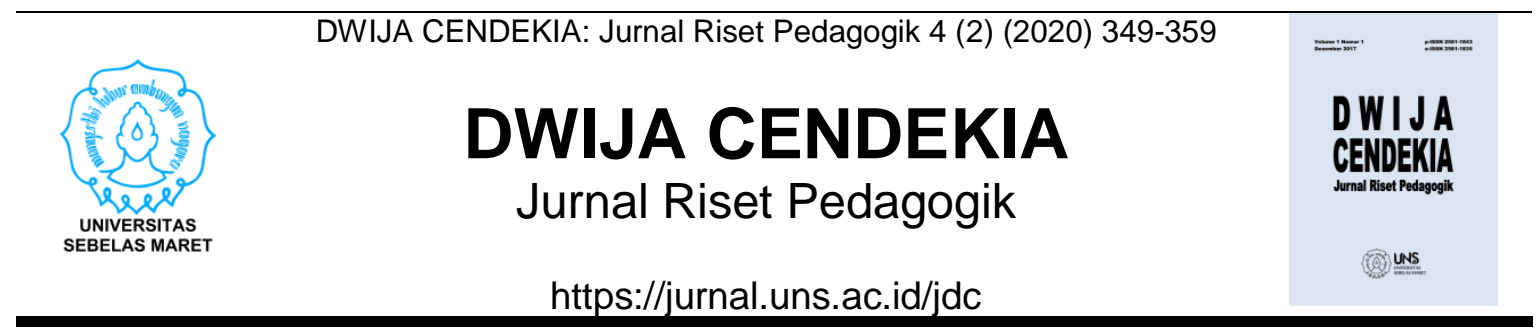

\title{
Pengaruh Lingkungan Keluarga dan Minat Belajar Terhadap Hasil Belajar Matematika Peserta Didik Kelas V Sekolah Dasar Tahun Ajaran 2019/2020
}

\author{
Siwi Utaminingtyas, Subaryana, Siti Fatimah
}

IKIP PGRI WATES

siwiutami66@gmail.com

Sejarah Artikel

diterima 7 November 2020 disetujui 20 November 2020 diterbitkan 1 Desember 2020

\begin{abstract}
This study aims to determine the effect of family environment and interest in learning on mathematics learning outcomes. This research uses a quantitative approach with the ex post facto method. The research population for Class V SD in Cluster III of Galur District for the 2019/2020 school year. The technique of taking is purposive sampling. The instruments used were a family environment questionnaire and a learning interest questionnaire. The data analysis technique used descriptive analysis and simple regression analysis and multiple regression to test the hypothesis. The results of the study prove that there is an influence of the family environment and interest in learning together / simultaneously on the mathematics learning outcomes of students in class V Elementary Schools in Cluster III Galur District for the $2019 / 2020$ Academic Year with R2 value of $45.7 \%$ and tcount> ttable $(18,052>3,244)$ with a significance level of $5 \%$. A family environment that pays good attention to their children's education and is supported by high interest in learning, has an impact on children's enthusiasm for learning, so that students can easily achieve satisfying learning outcomes.

Keywords: family environment, learning interest, mathematics learning outcomes
\end{abstract}

\section{Abstrak}

Penelitian ini bertujuan untuk mengetahui pengaruh lingkungan keluarga dan minat belajar terhadap hasil belajar matematika. Penelitian ini menggunakan pendekatan kuantitatif dengan metode Ex post facto. Populasi penelitian kelas V SD se-Gugus III Kecamatan Galur tahun ajaran 2019/2020. Teknik pengambilan dengan purposive sampling. Instrumen yang digunakan yaitu angket lingkungan keluarga dan angket minat belajar. Teknik analisis data menggunakan analisis dekriptif dan analisis regresi sederhana dan regresi berganda untuk menguji hipotesis. Hasil penelitian membuktikan bahwa ada pengaruh lingkungan keluarga dan minat belajar secara bersama-sama/simultan terhadap hasil belajar matematika peserta didik kelas $\mathrm{V}$ Sekolah Dasar se-Gugus III Kecamatan Galur Tahun Ajaran 2019/2020 dengan nilai R $^{2}$ sebesar 45,7\% dan thitung $>$ tabel $(18,052>3,244)$ dengan taraf signifikansi $5 \%$. Lingkungan keluarga yang memberikan perhatian pada pendidikan anaknya dengan baik dan didukung minat belajar peserta didik yang tinggi, berdampak pada semangat anak dalam belajar, sehingga peserta didik mudah meraih hasil belajar yang memuaskan.

Kata Kunci: lingkungan keluarga, minat belajar, hasil belajar matematika 


\section{PENDAHULUAN}

Pembelajaran merupakan proses kegiatan belajar mengajar yang memegang peranan penting dalam menentukan keberhasilan belajar peserta didik. Dalam pembelajaran, guru dan peserta didik merupakan dua komponen yang tidak bias dipisahkan. Antara dua komponen tersebut saling terjadi interaksi yang saling menunjang sehingga hasil belajar tercapai secara optimal. Namun perlu digaris bawahi bahwa guru bukanlah satu-satunya penentu keberhasilan belajar peserta didik. Keberhasilan peserta didik dalam penguasaan materi pembelajaran dapat dilihat dengan mengamati hasil belajarnya.

Evitasari \& Setiyani (Astiti dan Widiana, 2017) hasil belajar adalah tingkah laku peserta didik yang muncul setelah proses pembelajaran di kelas. Hasil belajar peserta didik dapat dipengaruhi oleh berbagai faktor, baik faktor dari dalam diri maupun faktor dari luar peserta didik. Menurut Slameto (2015) ada dua faktor yang mempengaruhi hasil belajar peserta didik, yaitu faktor intern dan faktor ekstern. Faktor intern meliputi faktor jasmani (faktor kesehatan dan cacat tubuh), faktor psikologis (inteligensi, perhatian, minat, bakat, motif, kematangan dan kesiapan) dan faktor kelelahan (kelelahan jasmani dan kelelahan rohani).

$$
\text { Faktor }
$$
ekstern

yang mempengaruhi hasil belajar peserta didik antaralain faktor keluarga (cara orang tua mendidik, relasi antar anggota keluarga, suasana rumah, keadaan ekonomi keluarga, pengertian orang tua dan latar belakang kebudayaan), faktor sekolah (metode mengajar, kurikulum, relasi guru dengan peserta didik, relasi peserta didik dengan peserta didik, disiplin sekolah, alat pelajaran, waktu sekolah, standar pelajaran diatas ukuran, keadaan gedung, metode belajar dan tugas rumah), faktor masyarakat (kegiatan peserta didik dalam masyarakat, media massa, teman bergaul, bentuk kehidupan masyarakat). Hal ini sejalan dengan penelitian yang dilaksanakan oleh Fitrianti \& Nur (2018) The results of data analysis obtained by school facilities and infrastructure have a relationship with teacher factors as a construct indicator of external factors. School facilities and infrastructure may be affiliated with students' perceptions of teaching mathematics teachers.

Dalam penelitian ini, yang menjadi fokus peneliti adalah faktor intern yaitu minat belajar dan faktor ekstern yaitu lingkungan keluarga. Lingkungan keluarga merupakan lingkungan pertama peserta didik memperoleh pendidikan. Hal ini sejalan dengan pendapat Durisic \& Bunijeva (2017), Educators and parents play major roles in the educational success of students. Berdasarkan penelitian yang dilakukan oleh Kurniawan, J \& Effendi Z.M., (2018) menyatakan bahwa family factor has a positive and significant effect on academic results students. The family environment gives the first influence in the formation of one's personality. The family is where the first learning process takes place; thus, it is expected to instigate good learning habits. Keluarga yang harmonis dan kondusif membuat peserta didik nyaman untuk belajar, sehingga berdampak langsung pada pencapaian pada prestasi. Begitu pula sebaliknya, keluarga yang kurang 
harmonis dan tidak konusif menyebabkan anak tidak nyaman belajar di rumah, anak tidak fokus dalam belajar dan berdampak pada hasil dan prestasi peserta didik.

Selain faktor keluarga, faktor yang menjadi fokus penelitian adalah minat belajar peserta didik. Kpolovie, Joe, \& Okoto (2014) minat kecenderungan jiwa untuk mendapatkan sesuatu karena siswa tersebut merasakan hal yang menarik dalam belajar, yang umumnya ditandai dengan perasaan senang. Triarisanti \& Pupung (2019), menyatakan bahwa interest in learning contributes greatly to the success of learners, hal ini menyatakan bahwa minat belajar mempunyai kontribusi yang besar bagi keberhasilan peserta didik. Dengan demikian, minat merupakan hubungan antara diri sendiri dengan sesuatu dari luar diri, apabila semakin kuat dan dekat hubungan tersebut maka semakin kuat pula minatnya. Hal ini dapat digaris bawahi bahwa apabila minat belajar peserta didik tinggi maka ketertarikan terhadap suatu objek juga tinggi, termasuk minat terhadap pembelajaran di kelas.

Minat belajar sangatlah penting dimiliki oleh peserta didik, jika peserta didik tertarik atau mempunyai minat terhadap suatu pembelajaran, maka pembelajaran tersebut akan mudah diterima dan tersimpan dalam memori peserta didik. Hal ini sejalan dengan pendapat Halim (2019), menyatakan bahwa One of the factor that influence in learning is students' interest, because when the lessons not in accordance with the students' interests, the students will not good in learning, because there is no power full for the students. The students are reluctant to study and not get satisfaction from the lesson. Teaching materials have attracted the interest of the students and they will be more easily learn and store.

Arlianti (2016) Interest is a powerful dictator and motivator in the learning process. Students are likely to pay attention to engangein more learning activities when their interest and emotions are positively provoked. Interest is a tendency to seek out and participate in any learning activities. Minat belajar menjadi pendorong dan unsur ketertarikan peserta didik dalam proses pembelajaran di kelas. Jika seorang anak berminat terhadap suatu pelajaran, maka ia akan memiliki ketertarikan terhadap pembelajaran tersebut. Hal ini berdampak pada si anak akan rajin belajar dan antusias mengikuti pembelajaran di kelasnya.

Berdasarkan hasil observasi di kelas V SD Se Gugus III Kecamatan Galur, peserta didik kurang berminat terhadap pembelajaran Matematika. Hal ini disebabkan karena pembelajaran berpusat pada guru, peserta didik cenderung pasif, hal ini berdampak pada minat peserta didik terhadap pembelajaran Matematika sehingga hasil belajar peserta didik yang tidak memenuhi KKM (Kriteria Ketuntasan Minimal) sehingga perlu mengikuti remedial.

Sedangkan dari hasil wawancara dengan peserta didik kelas V SD Se Gugus III Kecamatan Galur, peserta didik menganggap bahwa pembelajaran Matematika merupakan pembelajaran yang sulit dan rumit, banyak hafalan dan rumus-rumus, ditambah lagi peserta didik tidak mengulanginya di rumah. Peserta didik kurang mendapatkan bimbingan dan dorongan dari keluarga. Lingkungan keluarga juga harus berperan serta dalam keberhasilan peserta didik. Faktor perhatian, tinggi rendahnya pendidikan orangtua, besar 
kecilnya penghasilan orangtua, tenang atau tidaknya situasi di dalam rumah, semua ini turut mempengaruhi tinggi rendahnya hasil belajar peserta didik.

Dengan uraian latar belakang masalah di atas, maka peneliti ingin melakukan penelitian dengan judul
"Pengaruh Lingkungan Keluarga dan Minat Belajar Terhadap Hasil Belajar Matematika Peserta Didik Kelas V Sekolah Dasar Se-Gugus III Kecamatan Galur Tahun Ajaran 2019/2020".

\section{METODE}

Jenis penelitian yang digunakan adalah penelitian ex post facto. Sugiyono (Lestari dan Yudhanegara, 2017) penelitian ex post facto merupakan penelitian yang dilaksanakan untuk meneliti suatu peristiwa yang telah terjadi, meninjau ke belakang untuk mengetahui faktorfaktor penyebab-nya, peneliti tidak melakukan manipulasi terhadap variabel-variabel dalam penelitian.

Penelitian ini bertujuan untuk mengetahui pengaruh dari variabel bebas yaitu Lingkungan Keluarga $\left(X_{1}\right)$ dan Minat Belajar $\left(X_{2}\right)$ terhadap variabel terikat yaitu Hasil Belajar Matematika (Y). Pendekatan yang digunakan dalam penelitian ini yaitu pendekatan kuantitatif, karena data yang terkumpul berbentuk angka dan analisisnya menggunakan statistik.

Penelitian dilaksanakan pada peserta didik kelas V SD Se Gugus III Kecamatan Galur tahun ajaran 2019/2020. Penelitian menggunakan penelitian populasi dan sampel. Sugiyono (2016) populasi adalah wilayah generalisasi yang terdiri atas objek yang mempunyai kualitas dan karakteristik tertentu. Pada penelitian ini populasi nya adalah seluruh peserta didik kelas V SD Se Gugus III Kecamatan Galur tahun ajaran 2019/ 2020. Populasi Kelas V SD Se Gugus III Kecamatan Galur

Populasi dalam penelitian ini adalah seluruh peserta didik kelas $\mathrm{V}$ SD se-Gugus III Kecamatan Galur tahun ajaran 2019/2020. SD Sidakan dengan peserta didik 20, SDN I Bunder 12 peserta didik, SDN II Bunder 21 peserta didik, SDN Trisik 11 peserta didik, SD Muh I Banaran 19 peserta didik dan SD Muh II Banaran 18 peserta didik. Total populasi adalah 101 peserta didik.

Teknik sampel yang digunakan pada penelitian ini adalah purposive sampling. Menurut Arikunto (2010) "purposive sampling adalah menentukan sampel dengan pertimbangan tertentu yang dipandang dapat memberikan data secara maksimal". Sampel dalam penelitian ini adalah SD Negeri Sidakan dan SD Negeri II Bunder dengan total jumlah sampel yaitu 41 peserta didik.

Teknik pengumpulan data dalam penelitian ini adalah teknik angket dan dokumentasi. Variabel-variabel yang digunakan dalam penelitian ini adalah lingkungan keluarga (X1) dan minat belajar peserta didik (X2) serta hasil belajar matematika peserta didik (Y). Berdasarkan hasil wawancara dengan Guru Kelas berdasarkan hasil PAS kelas sebelumnya diantara ketiga ranah aspek pembelajaran, hasil kognitif pelajaran Matematika rata-rata masih di bawah KKM. Aspek kognitif Inilah yang menjadi fokus penelitian. Indikator hasil belajar matematika dalam penelitian ini, yaitu dengan nilai murni penilaian tengah semester (PTS) ganjil peserta didik kelas V SD 
se-Gugus III Kecamatan Galur tahun instrumen dalam penelitian sebagai ajaran 2019/2020. Adapun kisi-kisi berikut:

Tabel 1.

Kisi-kisi Angket Lingkungan Keluarga

\begin{tabular}{|c|c|c|c|c|}
\hline \multirow[t]{2}{*}{ No } & \multirow[t]{2}{*}{ Indikator } & \multicolumn{2}{|c|}{ No. Item } & \multirow[t]{2}{*}{ Jml } \\
\hline & & Positif & Negatif & \\
\hline 1. & Cara orang tua mendidik & $1,2,4$ & 3,5 & 5 \\
\hline 2. & $\begin{array}{c}\text { Relasi antar anggota } \\
\text { keluarga }\end{array}$ & $6,7,10$ & 8,9 & 5 \\
\hline 3. & Suasana rumah & $\begin{array}{c}11,13 \\
14\end{array}$ & 12,15 & 5 \\
\hline 4. & Keadaan ekonomi keluarga & $\begin{array}{c}16,17 \\
20\end{array}$ & 18,19 & 5 \\
\hline 5. & Pengertian orang tua & $\begin{array}{l}21,22 \\
23\end{array}$ & 24,25 & 5 \\
\hline 6. & Latar belakang kebudayaan & $\begin{array}{l}26,27 \\
28\end{array}$ & 29,30 & 5 \\
\hline
\end{tabular}

Sumber: Adaptasi dari Slameto (2015)

Tabel 2.

Kisi-kisi Angket Minat Belajar

\begin{tabular}{|c|c|c|c|c|}
\hline \multirow[t]{2}{*}{ No } & \multirow[t]{2}{*}{ Indikator } & \multicolumn{2}{|c|}{ No. Item } & \multirow[t]{2}{*}{ Jml } \\
\hline & & Positif & Negatif & \\
\hline 1. & $\begin{array}{c}\text { Belajar tanpa ada yang } \\
\text { menyuruh }\end{array}$ & $1,2,3,4$ & $5,6,7,8$ & 8 \\
\hline 2. & $\begin{array}{l}\text { Aktif dalam kegiatan } \\
\text { pembelajaran }\end{array}$ & $\begin{array}{c}9,11,13 \\
15\end{array}$ & $10,12,14$ & 7 \\
\hline 3. & $\begin{array}{l}\text { Memberikan perhatian } \\
\text { terhadap pembelajaran }\end{array}$ & $\begin{array}{c}16,17,21 \\
22\end{array}$ & $18,19,20$ & 7 \\
\hline 4. & $\begin{array}{l}\text { Menghafal pelajaran } \\
\text { yang diminatinya } \\
\text { Jumlah total item }\end{array}$ & $\begin{array}{l}23,24,25 \\
\quad 26,30\end{array}$ & $27,28,29$ & 8 \\
\hline
\end{tabular}

Sumber: Adaptasi dari Djamarah (2008)

gugur berjumlah 8 butir. Pada lembar

Berdasarkan pada hasil uji kuesioner minat belajar (X2) item yang validitas, menunjukkan bahwa untuk valid berjumlah 26 butir dan item yang lembar kuesioner pada variabel gugur berjumlah 4 butir. Sehingga lingkungan keluarga (X1) item yang diperoleh kisi-kisi sebagai berikut:

valid berjumlah 22 butir dan item yang

Tabel 3.

Hasil Uji Validitas Instrumen

\begin{tabular}{cccc}
\hline Variabel & $\begin{array}{c}\text { Jml item } \\
\text { semula }\end{array}$ & Nomor item gugur & $\begin{array}{c}\text { Jml item } \\
\text { valid }\end{array}$ \\
\hline Lingkungan keluarga & 30 & $1,5,11,17,19,24,26$, & 22 \\
(X1) & 30 & 30 & \\
Minat belajar (X2) & 60 & $6,11,21,26$ & 26 \\
Jumlah total & & 12 & 48 \\
\hline
\end{tabular}

Analisis data yang digunakan diketahui sebaran datanya. adalah analisis deskriptif, yang Sedangkan uji prasyarat analisis bertujuan untuk mendeskripsikan menggunakan uji normalitas, uji variabel-variabel penelitian sehingga linieritas, uji multikolinieritas, uji 
heteroskedasitas, dan uji regresi sederhana dan analisis regresi homogenitas.

Untuk pengujian hipotesis pada berganda.

penelitian ini menggunakan analisis

\section{PEMBAHASAN}

Penelitian ini terdiri atas 3 variabel, yaitu lingkungan keluarga (X1) dan minat belajar peserta didik (X2) serta hasil belajar matematika peserta didik (Y). Berdasarkan uji prasyarat analisis, dinyatakan bahwa variabel lingkungan keluarga, variabel minat belajar, dan variabel hasil belajar matematika berdistribusi normal, mempunyai hubungan linier (Linieritas), tidak terjadi multikolinieritas, homogen, dan tidak terjadi heteroskedastisitas.

Analisis korelasi sederhana digunakan untuk mengetahui keeratan hubungan antara dua variabel penelitian. Hasil dari analisis korelasi sederhana menyatakan bahwa variabel lingkungan keluarga (X1) dan hasil belajar $(\mathrm{Y})$ nilai correlation sebesar 0,618 dengan nilai signifikansi 0,002 maka antara variabel lingkungan keluarga dan hasil belajar memiliki hubungan yang signifikan, karena $(0,002<0,05)$. Hubungan ini berada pada tingkat yang kuat karena nilai korelasi berada pada rentang $0,60-0,799$. Sedangkan minat belajar (X2) dan hasil belajar (Y) nilai correlation sebesar 0,674 dengan nilai signifikansi 0,001 maka antara variabel minat belajar dan hasil belajar memiliki hubungan yang signifikan karena $(0,001<0,05)$. Hubungan ini berada pada tingkat yang kuat karena nilai korelasi berada direntang 0,60 0,799 .

Untuk menguji hipotesis 1 dan hipotesis 2 menggunakan uji regeresi sederhana. Hipotesis pertama membuktikan bahwa Ada pengaruh lingkungan keluarga terhadap hasil belajar matematika peserta didik kelas V Sekolah Dasar se-Gugus III Kecamatan Galur Tahun Ajaran 2019/2020. Hal ini terlihat dari hasil signifikansi sebesar 0,002 sehingga hipotesis 1 diterima, karena 0,002 < 0,05 . Sedangkan pada thitung sebesar 3,298 dan tabel sebesar 1,685. Dengan demikian, thitung $>$ tabel $(3,298>1,685)$. Jadi, ada pengaruh lingkungan keluarga terhadap hasil belajar matematika peserta didik kelas $\mathrm{V}$ Sekolah Dasar se-Gugus III Kecamatan Galur Tahun Ajaran 2019/2020.

Keseluruhan aspek lingkungan keluarga (cara mendidik anak, relasi antar anggota keluarga, suasana rumah, keadaan ekonomi keluarga, pengertian orang tua, dan latar belakang kebudayaan berpengaruh positif terhadap hasil belajar peserta didik. Hal ini sejalan dengan penelitian Ningrum (2016) bahwa pola asuh orang tua (mendidik anak, berkomunikasi dengan anak, respon terhadap kebutuhan anak, perhatian terhadap anak, dan kebiasaan meluangkan waktu dengan anak) berpengaruh positif terhadap hasil belajar anak.

Selain pola asuh pendapatan orangtua mempengaruhi keberhasilan anak dalam belajar, hal ini sejalan dengan Williams (2002) The analysis of relationships in this study indicated that family income was more closely related to success; there was a positive relationship between family income and Brigance scores $(r=$ 
.295). Generally, students with higher Brigance scores came from families with higher incomes. Keluarga dengan pendapatan sedang ke tinggi tentunya akan lebih menunjang kebutuhan anak dalam belajar baik dari alat tulis, buku penunjang, mengikuti les tambahan dan tempat yang nyaman untuk belajar di rumah. Begitu juga dengan hubungan keluarga yang harmonis, dan suasana rumah yang nyaman membuat peserta didik merasa nyaman belajar sehingga memperoleh hasil belajar yang memuaskan (Apriyanti dan Candrasari, 2011).

Hipotesis kedua membuktikan bahwa Ada pengaruh minat belajar terhadap hasil belajar matematika peserta didik kelas $\mathrm{V}$ Sekolah Dasar se-Gugus III Kecamatan Galur Tahun Ajaran 2019/2020. Hal ini terlihat dari nilai signifikansi sebesar 0,001 sehingga hipotesis 2 diterima karena $0,001<0,05$. Sedangkan pada thitung sebesar 5,862 dan tabel sebesar 1,685. Dengan demikian, thitung $>$ tabel $(5,862>$ 1685). Jadi, ada pengaruh minat belajar terhadap hasil belajar matematika peserta didik kelas $\mathrm{V}$ Sekolah Dasar se-Gugus III Kecamatan Galur Tahun Ajaran 2019/2020.

Minat belajar pada peserta didik dalam aspek (belajar tanpa ada yang menyuruh, aktif dalam kegiatan pembelajaran, memberikan perhatian terhadap pembejaran dan menghafal pelajaran yang diminati) berpengaruh positif terhadap hasil belajar peserta didik. Hal ini sejalan dengan penelitian Ricardo \& Meilani (2017), bahwa aspek perhatian dan konsentrasi besar terhadap pembelajaran, perasaan tertarik dan senang terhadap pembelajaran, berpartisipasi aktif, kemauan untuk belajar, kenyamanan dalam belajar terbukti berjalan satu arah. Jika variabel minat belajar meningkat, maka variabel hasil belajar siswa juga akan meningkat begitupun sebaliknya.

Untuk menguji hipotesis ke 3 menggunakan uju regresi ganda. Analisis regresi ganda digunakan untuk mengetahui pengaruh antara 2 atau lebih variabel bebas dengan satu variabel terikat. Hipotesis ketiga membuktikan bahwa Ada pengaruh lingkungan keluarga dan minat belajar secara bersama-sama terhadap hasil belajar matematika peserta didik kelas V Sekolah Dasar se-Gugus III Kecamatan Galur Tahun Ajaran 2019/2020. Bahwa diperoleh F Fitung $>F_{\text {tabel }}$ yaitu $18,052>3,244$ dan signifikansi yaitu $0,002<0,05$ sehingga hipotesis 3 diterima, yang artinya ada pengaruh lingkungan keluarga dan minat belajar secara bersama-sama terhadap hasil belajar matematika peserta didik kelas $\mathrm{V}$ Sekolah Dasar se-Gugus III Kecamatan Galur Tahun Ajaran 2019/2020.

Hal ini sejalan dengan penelitian Rosfiani, Akbar, \& Neolaka (2019), Tresnati (2016), Sari (2016) menyatakan bahwa lingkungan keluarga dan minat belajar berpengaruh positif terhadap hasil belajar siswa. Peran keluarga dalam meningkatkan belajar anak sangat diperlukan. Ketika orangtua atau keluarga tidak memperhatikan anak dalam belajar maka yang akan terjadi adalah munculnya sikap malas dan kurang berminat dalam belajar, baik belajar di rumah maupun di sekolah. Tetapi jika orangtua memperhatikan pendidikan anaknya dalam belajar, menciptakan suasana rumah yang nyaman, menyediakan sarana prasarana dalam menunjang belajar, dan memberikan dorongan dalam belajar tentunya akan timbul rasa 
semangat dan minat anak dalam belajar.

Minat menjadi salah satu faktor penentu dalam pencapaian hasil belajar. Sembiring \& Mukhtar (2013) mengemukakan bahwa hasil belajar Matematika siswa yang mempunyai minat belajar yang tinggi maka hasilnya pun memuaskan daripada siswa yang memiliki minat belajar yang rendah. Jadi dapat ditarik suatu kesimpulan bahwa ketika minat siswa rendah dalam mengikuti kegiatan pembelajaran maka hasil yang diperoleh kurang memuaskan, namun sebalinya apabila minat siswa dalam mengikuti kegiatan belajar tinggi maka siswa dapat mencapai keberhasilan dalam belajar sehingga memperoleh nilai belajar yang tinggi.
Lingkungan keluarga dan minat belajar yang dimiliki peserta didik memiliki peran yang sama besar terhadap keberhasilan belajar anak yang ditunjukkan dengan nilai belajar yang tinggi, hal ini sesuai dengan pendapat Slameto (2015) sebuah keluarga yang harmonis dan mendukung belajar anak, maka seorang anak cenderung memiliki minat yang tinggi untuk belajar, sehingga akan memperoleh hasil belajar yang tinggi. Sebaliknya, apabila keluarga kurang harmonis dan tidak mendukung belajar anak, maka seorang anak cenderung tidak memiliki minat belajar yang tinggi, sehingga akan memperoleh hasil belajar yang kurang memuaskan.

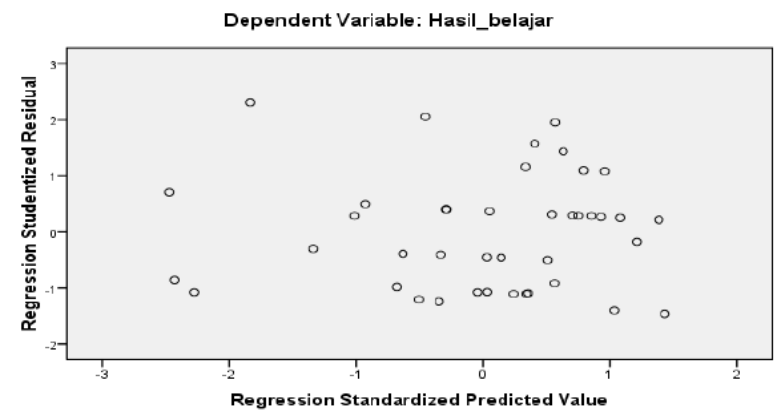

Gambar 1. Pola Scatter Plots

Tabel 5.

Hasil analisis Regresi Sederhana

\begin{tabular}{|c|c|c|c|c|}
\hline \multicolumn{5}{|c|}{ Coefficients $^{\mathrm{a}}$} \\
\hline \multicolumn{2}{|c|}{$\begin{array}{l}\text { Unstandardized } \\
\text { Coefficients }\end{array}$} & $\begin{array}{l}\text { Standardized } \\
\text { Coefficients }\end{array}$ & & \\
\hline B & Std. Error & Beta & $\mathrm{T}$ & Sig. \\
\hline-9.674 & 20.435 & & -.426 & .665 \\
\hline .842 & .290 & .618 & 3.298 & .002 \\
\hline
\end{tabular}




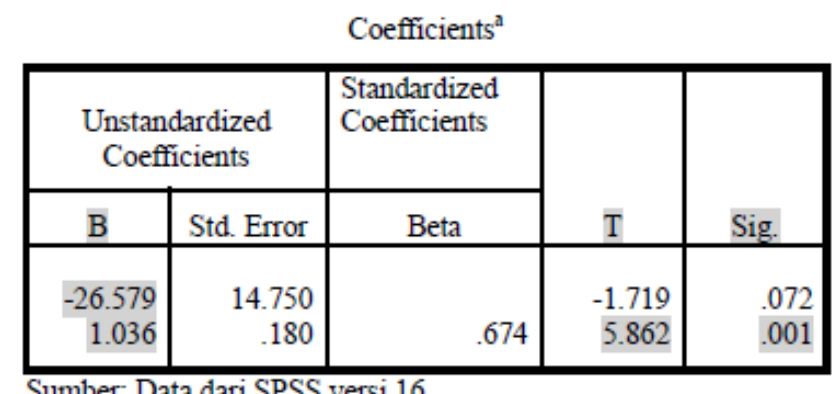

Sumber: Data dari SPSS versi 16

Tabel 6.

Hasil Uji Simultan

\begin{tabular}{|r|r|r|c|r|}
\hline Sum of Squares & Df & Mean Square & F & Sig. \\
\hline 7317.593 & 2 & 3587.796 & 18.052 & .002 \\
8779.528 & 38 & 185.527 & & \\
16097.122 & 40 & & & \\
\hline
\end{tabular}
a. Predictors: (Constant), $\mathrm{X}_{1 .} \mathrm{X}_{2}$
b. Dependent Variable: $\mathrm{Y}$

\section{SIMPULAN}

Simpulan yang dapat diperoleh dari penelitian ini, sebagai berikut:

1. Berdasarkan hasil perhitungan data penelitian, bahwa ada pengaruh lingkungan keluarga terhadap hasil belajar matematika peserta didik kelas V SD se-Gugus III Kecamatan Galur. Kemudian diperoleh koefisien determinasi sebesar 0,408 yang artinya bahwa pengaruh lingkungan keluarga terhadap hasil belajar matematika peserta didik kelas V SD se-Gugus III Kecamatan Galur yaitu sebesar $40,8 \%$ dan sisanya $59,2 \%$ dipengaruhi oleh faktor lain.

2. Berdasarkan hasil perhitungan data penelitian, bahwa ada pengaruh minat belajar terhadap hasil belajar matematika peserta didik kelas $\mathrm{V}$ SD se-Gugus III Kecamatan Galur. Kemudian diperoleh koefisien determinasi sebesar 0,436 yang artinya bahwa pengaruh minat belajar terhadap hasil belajar matematika peserta didik kelas $\mathrm{V}$ SD se-Gugus III Kecamatan Galur sebesar $43,6 \%$ dan sisanya $56,4 \%$ dipengaruhi oleh faktor lain.

3. Berdasarkan hasil perhitungan data penelitian, bahwa ada pengaruh lingkungan keluarga dan minat belajar secara bersama-sama terhadap hasil belajar matematika peserta didik. Kemudian diperoleh koefisien determinasi sebesar 0,457 yang artinya bahwa pengaruh lingkungan keluarga dan minat belajar secara bersamasama/simultan terhadap hasil belajar matematika peserta didik kelas V SD se-Gugus III Kecamatan Galur sebesar 45,7\% dan sisanya $54,3 \%$ dipengaruhi oleh faktor lain. 


\section{DAFTAR PUSTAKA}

Apriyanti, M \& Candrasari, A. (2011). Family's Role And Learning Achievement Of Elementary School's Age Children. International Journal of Social Sciences and Education. 1 (2) : 79 $-85$.

Arikunto. (2010). Prosedur Penelitian Suatu Pendekatan Praktek. Jakarta: Rineka Cipta.

Arlyanty, W.N. (2017). An analysis of interest in students learning of physical chemistry experiment using Scientific approach. International Journal of Science and Applied Science: Conference Series. 1 (2) : 109 - 116. Diakses pada tanggal 7 November 2020 pukul 22:47 dari https://jurnal.uns.ac.id/ijsascs/artic le/view/5130/4588.

Evitasari, A.D. \& Setiyani W. (2020). Model Cooperative Learning Tipe Jigsaw dalam Meningkatkan Hasil Belajar Peserta Didik pada Pembelajaran IPA Kelas V Sekolah Dasar. Taman Cendekia : Jurnal Pendidikan Ke-SD an. 4 (2) : 483 - 491.

Djamarah, S.B. (2008). Psikologi Belajar. Jakarta: Rineka Cipta.

Durisic, M \& Bunijevac, M. (2017). Parental Involvement as a Important Factor for Successful Education. CEPS Journal. 7 (3) : 137 - 153. Diakses pada tanggal 7 November 2020 pukul 22:03 dari https://files.eric.ed.gov/fulltext/EJ1 156936.pdf

Fitrianti, H \& Nur, A.S. (2018). Structural Model External and Internal Factors that Influence Students Mathematical Learning Achievement. International Confe- rence on Science and Technology. $1: 853-857$.

Halim, S. (2019). Interest In Foreign Language Learning. Journal of Language Teaching and Learning, Linguistics and Literature. 7(1): 134-143.

Kpolovie, P. J., Joe, A. I., \& Okoto, T. (2014). Academic Achievement Prediction: role of Interest in Learning and Attitude Towards School. International Journal of Humanities Social Sciences and Education. 1 (11), 73-100.

Kurniawan, J., Effendi Z.M., \& Dwita sani. (2018). The Effect of School Environment, Family Environment and Learning Motivation on Students' Learning Performance. Padang International Conference On Economics Education, Economics, Business and Management, Accounting and Entrepreneurship (PICEEBA) volume 57.

Lestari, K.E. dan Yudhanegara, M.R. (2017). Penelitian Pendidikan Matematika. Bandung: Refika Aditama.

Ningrum, W.R. (2016). Pengaruh Peranan Dan Pola Asuh Orang Tua Terhadap Hasil Belajar Siswa Sekolah Dasar Negeri Di Kecamatan Bogor Barat. Jurnal Pendidikan. 17 (2) : 129 - 137.

Ricardo \& Meilani, R.I. (2017). Impak Minat dan Motivasi terhadap Hasil Belajar Siswa. Jurnal Pendidikan. 2 (2), 188 - 201.

Rosfiani, O; Akbar, M; \& Neolaka, A. (2019). Assesing Student Social Studies Learning : Effects of Learning Environment, Inquiry, And Student Learning Interest. 
Tarbiya Journal of Education In Muslim Society. 6 (2), 46 - 57.

Sari, D. P. (2016). Pengaruh Lingkungan Keluarga dan Minat Belajar Terhadap Kemampuan Berhitung Pecahan Siswa Kelas Atas SD Negeri 1 Taruban Nogosari Boyolali Tahun Ajaran 2015/ 2016 (Skripsi). Surakarta : Universitas Muhammadiyah Surakarta.

Sembiring, R. Br. \& Mukhtar. (2013). Strategi Pembelajaran dan Minat Belajar terhadap Hasil belajar Matematika. Jurnal Teknologi Pendidikan. 6 (2), 214 -229.

Slameto. (2015). Belajar dan FaktorFaktor yang Mempengaruhinya. Jakarta: Rineka Cipta.

Sudjana, N. (2017). Penilaian Hasil Proses Belajar Mengajar. Bandung: Remaja Rosdakarya.

Suherman, Erman, Turmudi, Didi Suryadi, Tatang Herman, Suhendra, Sufyani, Nurjannah, dan Ade Rohayati. (2016). Strategi Pembelajaran
Matematika Kontemporer. Bandung: UPI.

Sugiyono. (2016). Metode Penelitian Kuantitatif, Kualitatif dan Kombinasi. Bandung: Alfabeta.

Tresnati, K.N. (2016). Hubungan Lingkungan Keluarga Dan Minat Belajar Terhadap Hasil Belajar IPS Siswa Kelas IV SD Di Gugus Kresna Dan Shinta Kecamatan Semarang Barat (Skripsi). Semarang : Universitas Negeri Semarang.

Triarisanti, R \& Pupung, P. (2019). The Influence Of Interest And Motivation On College Students' Language And Art Appreciation Learning Outcomes. International Journal Of Education. 11 (2) : 130135.

Williams, N.C. (2002). The Relationship of Home Environment and Kindergarten Readiness (Disertasi). Tannessee : East Tannessee State University. https://dc.etsu.edu/etd 